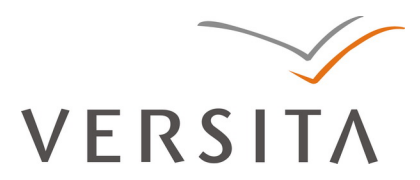

DOI: 10.2478/genst-2013-0021

\title{
GENDER AND POLITICS AS THE DOMINANT FACTORS IN THE PERCEPTIONS OF MULTICULTURAL EDUCATION
}

\author{
ALEKSANDRA IZGARJAN \\ aleksandraizgarjan@nscable.net \\ SLOBODANKA MARKOV \\ slobodanka.markov@gmail.com \\ DIANA PRODANOVIĆ-STANKIĆ \\ stankicd@eunet.rs \\ University of Novi Sad
}

Trg Dositeja Obradovića 5, 21000 Novi Sad

\begin{abstract}
The paper presents an analysis of research focusing on the attitudes of students at the University of Novi Sad, Serbia toward multiculturalism and on the intersection of the gender aspect and students' political affiliation. The results show that both gender and political affiliation shape student attitudes since more female students and those who identify themselves with the democratic block support multicultural education in comparison with those who identify themselves with the nationalist block.
\end{abstract}

Keywords: education, gender, multiculturalism, politics, students. 


\section{Introduction}

This paper presents a case study conducted at the University of Novi Sad to examine student attitudes towards multiculturalism (particularly in the educational process), with a special focus on the gender aspect and on intersections with the same students' opinions about ethnic tolerance and their stereotypes regarding ethnic communities in Serbia. Comparative analysis of the data collected in the previous study showed that the gender aspect is one of the factors that determine students' attitudes toward multicultural education and influence their opinions of ethnic minorities. For example, female students showed more confidence that multicultural education had shaped their perception of minorities (Izgarjan, Markov, Prodanović-Stankić 2012:263). In this paper we would like to present the results of the second phase of the research and examine the correlation between the students' gender and their political affiliation, i.e. the factors that proved to be decisive in shaping their attitudes toward ethnic minorities and the importance of multicultural education. Our statistical analysis was based on percentage share within the structures of the categories in the questionnaire while the calculations were carried out using the Minitab program package.

We decided to analyze the elements of multicultural education at the institutions of higher learning in Vojvodina because no research has so far been done to address this issue, despite the high ethnic diversity of its student body (particularly at the University of Novi Sad). Many argue that the introduction of the elements of multiculturalism into diverse ethnic communities is of special importance since it is "an attempt to foster an appreciation for cultural diversity, with the overall goal of developing within students a sense of esteem for 
different cultures. Holders of this perspective argue that knowledge of differences in world views, as shaped by culture, can enhance one's ability to interact with individuals and groups of diverse cultural backgrounds" (Seltzer 1995:125). Multicultural education progressed from dealing only with the issues of the curriculum "to a theoretical framework for (1) valuing demographic diversity as an enriching social context; (2) promoting a multicultural curriculum as a whole-school knowledge base; (3) promoting instructional strategies that structure heterogeneous, learner-centered, and critical processes; (4) promoting collaborative and unifying relationships among all the participants, not necessarily as service providers and clients, in the education enterprise; and (5) demanding personal commitments to these principles [...]. In keeping with this mandate for inclusiveness and social critique, transformational scholars and critical theorists argue that knowledge is not neutral but is influenced by human interests. Curricula do reflect the power and social relationships within a society" (Hidalgo et al. 2013), inevitably linking politics and education. While the concept of multiculturalism has met with support from those educators who promote cultural diversity, it has also aroused opposition from those who think that it gives students a false image of reality and the balance of power in society by introducing elements of the culture, history and traditions of ethnic minorities. Given the fact that from the beginning of the history of multicultural education, the broadening of the curriculum to include different voices was perceived not only as an educational but also as a political issue, we cannot afford to ignore the political agenda involved. Thus Mattai, commenting upon education in the United States, contends that in "most cases, attempts to introduce multiculturalism into the 
curriculum appear to be political responses, and efforts to infuse the American educational curriculum with multiculturalism largely partisan activities engaging only those few who are committed to effecting significant educational and societal changes" (quoted in Seltzer 1995:124). Consequently, the reason why the second phase of the research focused on analysis of the impact of students' political affiliation on their perception of multicultural education and ethnic minorities was our awareness of the fact that the political agenda has always been a part of multicultural education in Serbia (and elsewhere). Our research was based on the premise that in order to make multicultural education part of the system of higher learning in Serbia, we must first assess the attitudes of students as primary beneficiaries of such implementation. Further research will need to examine the attitudes of university staff and members of the community in general, since without wider support and understanding of multicultural educational processes we cannot hope to achieve revision not only of curricula but also of perceptions of such education and its objectives.

\subsection{Sample}

The full sample consisted of 533 students, 53.1 of whom were female and 46.91 male, which corresponds to the slightly higher number of female students at the University of Novi Sad in general. As can be seen in Chart 2, the national affiliation of the students who comprised the sample matches the national and ethnic composition of the student body at the University of Novi Sad. The majority of the students belong to the Serbian nationality $(76.62 \%)$, followed by those belonging to the Hungarian (9.52\%), Romani (5.59), Slovak (3.03), Ruthenian (1.73), Romanian (1.43), Croatian (0.87) and Montenegrin 
(0.87) communities. The political affiliation of the students encompasses all major political groups (Democrats 31.71\%, Nationalists 6.94\% and Socialists $4.5 \%)$. The large number of students (56.85\%) who did not identify themselves with any particular political group can be attributed to the general apathy in Serbia regarding the activities of political parties as well as to a major regrouping of political parties in the past four years.

\section{Previous Exposure of the Students to Multicultural Education}

We asked the students to give us their estimate of the degree of their exposure to multicultural education. When we take into account the differences between male and female students we can see that slightly more male than female students (44.4\% compared with $39.93 \%$ ) think that they have been sufficiently exposed to multicultural education (Chart 4). However, more female (53.71) than male (48.8\%) students think that they have been partially exposed. This is in line with the results of our previous study, which demonstrated that female students appear to be more dissatisfied with their exposure to multicultural education while male students appear to be more satisfied with the multicultural education they have received (Izgarjan, Markov, Prodanović-Stankić 2012:259). 


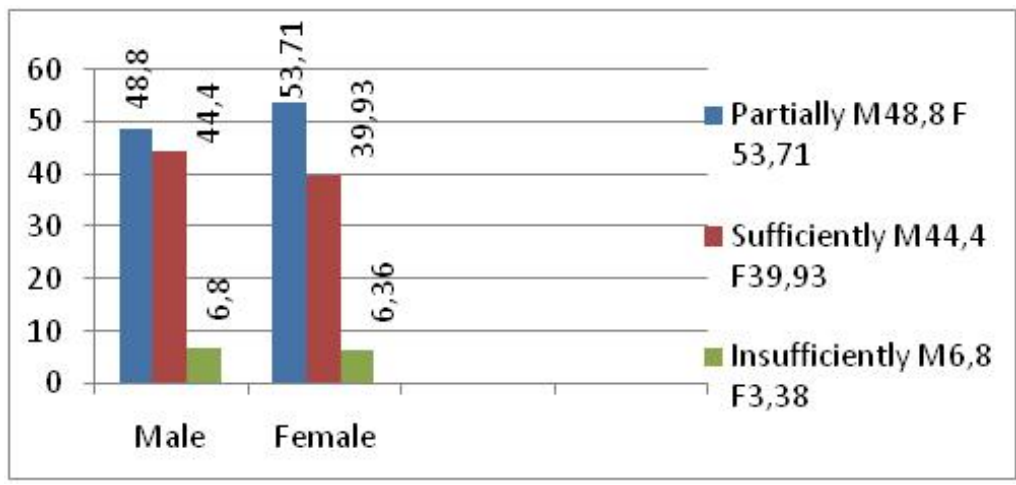

Chart 4

Answers to this question from within different political groups show a significant difference in the students' perceptions (Chart 5). It is predominantly those students who identify themselves with nationalist parties $(62.16 \%)$ who think that they have been sufficiently exposed to multicultural education, while $32.43 \%$ think that they have been partially exposed and only $5.42 \%$ think that they have been insufficiently exposed. Given the intolerance of nationalist parties toward ethnic minorities we may assume that students affiliated with such parties perceive their exposure to multicultural education as greater than it objectively is. We can also assume that students affiliated with nationalist parties do not value multicultural education, with the result that they consider sufficient any amount they receive. By contrast with them, half of the students affiliated with the democratic group (52.07\%) think that they have been partially exposed and $42.01 \%$ that they have been sufficiently exposed, so the difference between nationalists and democrats is around $20 \%$. Since ethnic tolerance and equality is an important aspect of the ideology of the democratic parties in Serbia, the students affiliated with these parties perceive elements of 
multicultural education in the curricula as valuable. We also see here that over half of all politically unaffiliated students (54.13\%) think that they have been sufficiently exposed and $39.27 \%$ that they have been partially exposed, so we can assume that their politically independent position enables them to have a more realistic picture of the extent of multicultural education at the University of Novi Sad. Students affiliated with the socialist group think that they have been sufficiently or partially exposed in almost the same percentage (45.13\% to $41.67 \%$ ), so we may conclude that there are no major differences between students affiliated with the democratic and socialist groups and those who are politically unaffiliated, while the differences between these students and students affiliated with the nationalist parties are considerable. The difference between democrats and undecided is $2 \%$ while the difference between undecided and socialists is around 5\%. Other research also supports these findings. Cockrell et al. found that resistance to multicultural education, based on the two principles of individualism and monoculturalism, was most prevalent among white male students (Cockrell 1999:359) while Seltzer et al. state that white conservative males were more likely to see problems with multicultural education than women (1995:135).

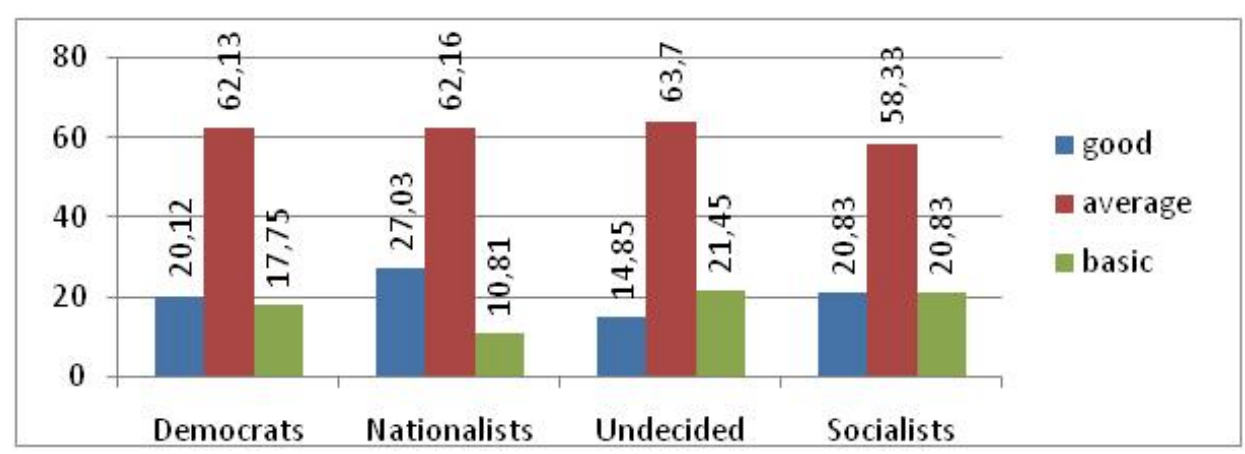




\section{Chart 5.}

When we take into account intersections of the gender aspect and political affiliation within each political group (Chart 6), major differences are noticeable within the nationalist group, where $70.59 \%$ of women think that they have been partially exposed in comparison to $55 \%$ of men. $29.41 \%$ of female nationalists in comparison to $35 \%$ of male ones think that they have been sufficiently exposed and none of these females think that they have been insufficiently exposed, while $10 \%$ of male nationalists think this. In the democratic group more female $(56.93 \%)$ than male (46.99\%) students think that they have been partially exposed but the differences are not so pronounced. The same is true in the case of socialists and unaffiliated students. We may conclude that within the political groups the differences between male and female students are negligible except within the nationalist group (nationalists $16 \%$, democrats $5 \%$, undecided $3 \%$; socialists $2 \%$ ).

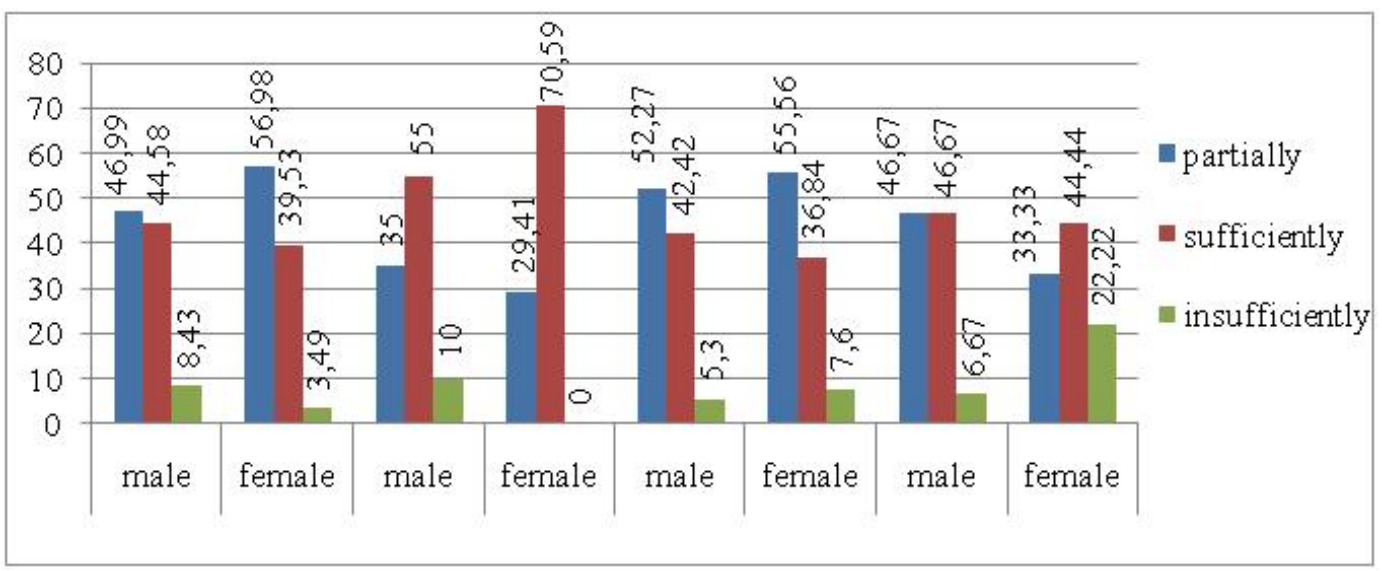




\section{Chart 6}

However, the greatest difference can be observed when we compare women's answers across the different political groups, which we think is particularly interesting. Thus there is a $31.06 \%$ difference between female democrats and female nationalists who answered that they had been sufficiently exposed to multicultural education and a $27.57 \%$ difference between those who answered that they had been partially exposed. The differences between their male counterparts are not so noticeable - $12 \%$ for partial exposure and $10.42 \%$ for sufficient. There are virtually no differences between female democrats and unaffiliated women in their answers to this question and only a 5\% difference between female democrats and female socialists. There is an even smaller difference between their male counterparts: for male democrats and undecided men the difference is $5 \%$ and for male democrats and male socialists the difference is less than $1 \%$.

Our interpretation of these results is that female students affiliated with the nationalist party want to prove their allegiance to the party and therefore reflect hard-core opinions. This can be more fully understood when we take into account the history of the nationalist block in Serbia. There were virtually no women in this block when it was formed, and in subsequent years although women formed part of the membership they did not occupy any leading positions. These parties were very patriarchal and perceived women primarily as wives and mothers. More importantly, women from the nationalist parties in Serbia never participated in the struggle to win more political power for all women and to ensure their participation in government, unlike women in the 
democratic block, who lobbied very actively for the law which specified that parliament must be 30\% female (Blagojević 1997:20, Mlađenović 2002:20). It was the passing of this law, among other factors, which pressured nationalist parties into appointing more women to leading positions, and these were always women who had already proved their unswerving allegiance to the party and shown rigid adherence to the party line. Female members of the nationalist party have, in fact, become notorious for their inappropriate behaviour in the Serbian Parliament (swearing at their opponents, throwing shoes and spitting water at them, wearing T-shirts with party slogans on them etc). This party history and the position of women within the party can explain the difference between these female students and the other students in the sample as well as the difference between them and their male nationalist counterparts. In Serbia, men generally tend to occupy more important positions both within the parties and in governmental and economic spheres so they do not need to prove their loyalty or to show their insecurity in the way that women do.

\subsection{The Impact of Multicultural Education on Students' Knowledge of Ethnic Minorities}

There are no significant differences between men and women within the whole sample as to the issue of the impact of multicultural education on students' knowledge of ethnic minorities. There is only a 3\% difference between men and women who think that their level of knowledge is good (Chart 7). 


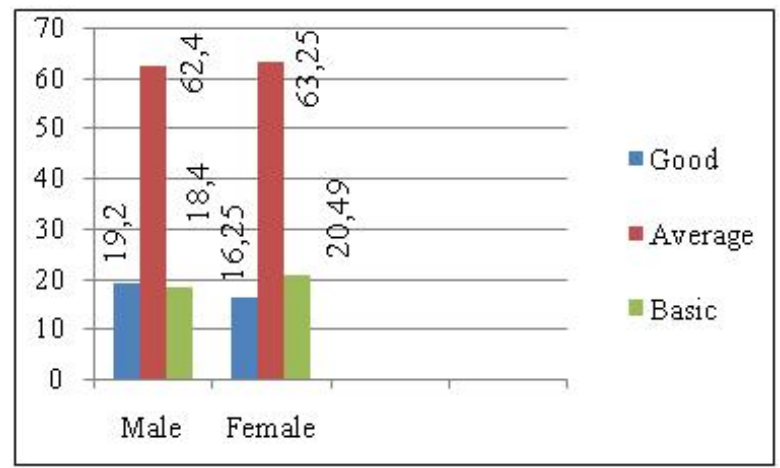

Chart 7

While the differences between political parties reflected in answers to this question are negligible as well, we can see that the trends are similar to those in the previous example. More nationalists perceive their knowledge as good (27.03) and the difference between them and other groups is around 10\% (Chart 8). Fewer nationalists than members of any other group perceive their knowledge as basic, the difference again being around $10 \%$. The variations among democrats, socialists and unaffiliated students are very small (below $5 \%$ ). The positive perception of their knowledge of ethnic minorities among students affiliated with the nationalist group can be attributed to their complacent attitude toward ethnic minorities and the absence of any feeling that they need to learn more about them (Cockrell 1999:356-58; Seltzer et al. 1995:128). The disparities among democrats, socialists and the undecided are not so sharply contrasted. Democrats and undecided students differ by only $2.57 \%$ and undecided and socialists by $5.37 \%$. 


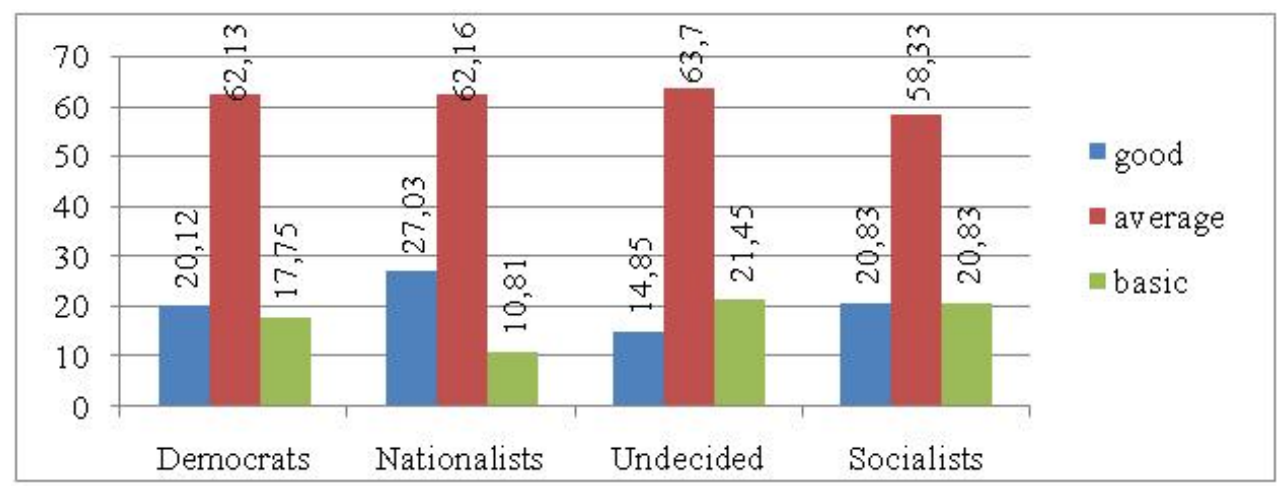

Chart 8

Analysis of the correlation between gender and political affiliation among men and women from different political blocks reveals major differences between female nationalists and socialists (29.41\%) (Chart 9). Thus no female socialists think that their knowledge of ethnic minorities is good, compared with $29.41 \%$ of nationalist women who think it is. Similarly $33.33 \%$ of female socialists think their knowledge is basic, a sharp contrast with the $5.88 \%$ of female nationalists who hold this view. The difference between the democratic and nationalist groups of women is $13.89 \%$ while the difference between democrats and undecided is $7.48 \%$ for good knowledge and $2 \%$ for average and basic. This significant disparity between female socialists and nationalists and the generally critical attitude of female socialists toward their knowledge of minorities can be explained by the values of the Socialist party in Serbia. It has traditionally been identified with former Yugoslavia, in which ethnic tolerance was promoted. Even today the Socialist party perceives this period of history and former Yugoslavia as exemplary, and this can account for the desire of female socialists to learn more about ethnic minorities and can explain why 
they perceive their knowledge as only average or basic. Unlike them, female nationalists do not have any such desires or aspirations. The attitudes shown by female socialists, which are more in line with the party ideology in this respect than those of their male counterparts, can be attributed to the more traditional attitudes of women within the party in general and the need to give "desirable" answers.

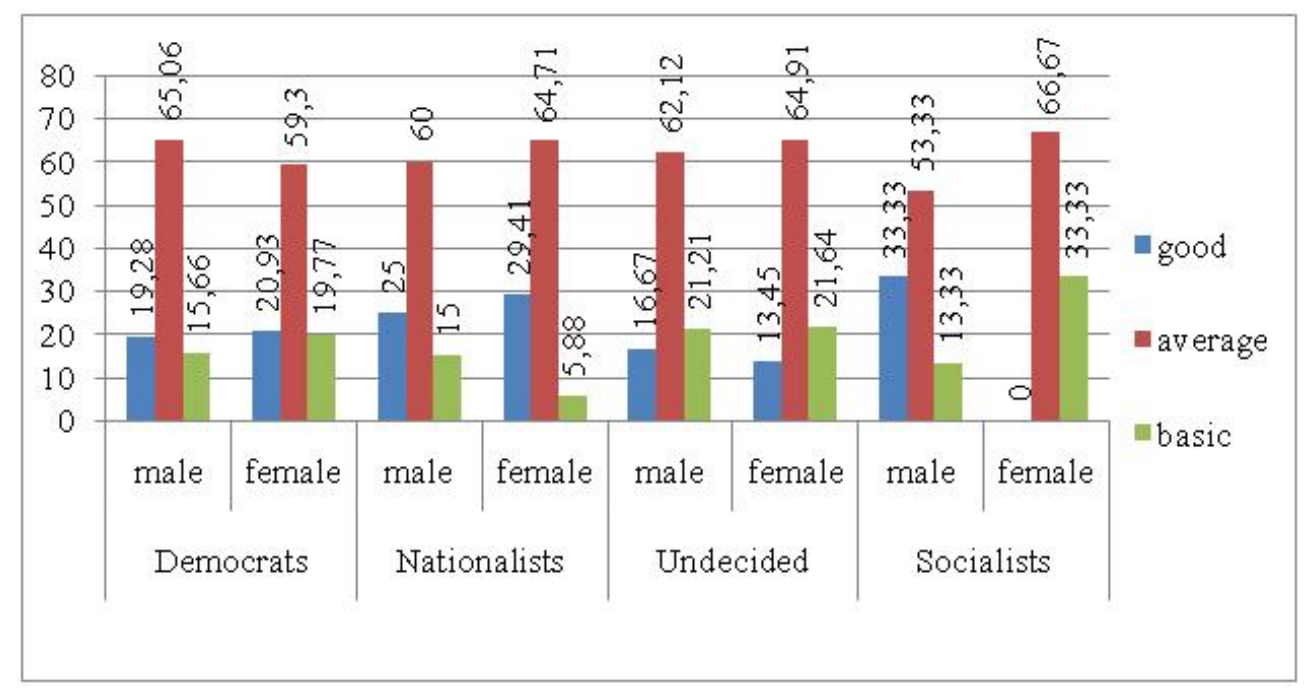

Chart 9

Disparities among men who belong to different parties are not so noticeable. Unlike in the case of their female counterparts, the difference between male nationalists and male socialists who think their knowledge of ethnic minorities is good is $8 \%$, average $7 \%$, and basic $1.67 \%$. The same can be said for male democrats and socialists with a difference of $12 \%$. There is a much smaller difference $(3 \%)$ between male democrats and unaffiliated male students. Interestingly, even between male democrats and male nationalists the difference 
is $5 \%$ for average knowledge and there is no difference between those who think that they have basic knowledge. The differences between men and women are again not very pronounced: $4.11 \%$ between male and female democrats, $6.5 \%$ between male and female nationalists, $9.12 \%$ between male and female nationalists and $13.34 \%$ between male and female socialists.

\subsection{Elements of Multiculturalism in the Curriculum}

When asked whether multicultural education should be included in the curriculum $61.48 \%$ of women answered positively, leading us to conclude that women, more than men, favor the presence of the elements of multicultural education (the difference being 8.68\%) (Chart 10). Previous research corroborates the finding that women tend to be more supportive of multicultural education and to perceive the need for its inclusion in the curriculum (Kehrberg 1990; Cockrell 1999:358; Izgarjan, Markov, Prodanović-Stankić, 2012:263264).

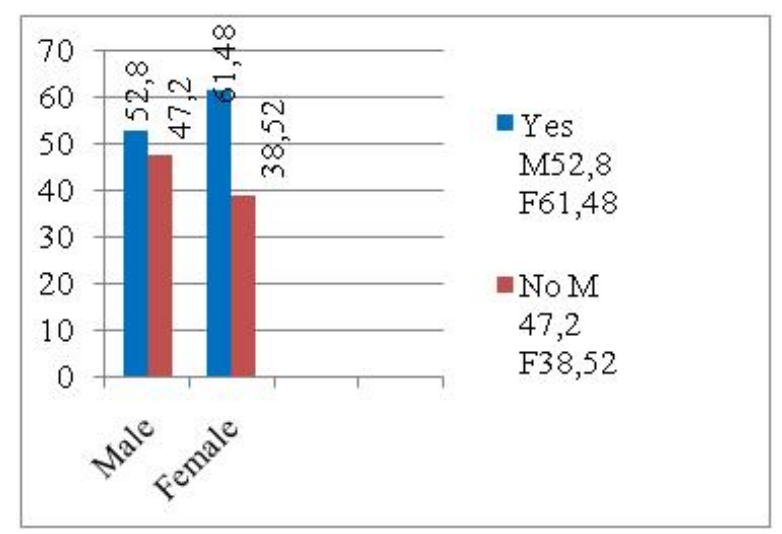

Chart 10 
We can clearly see in Chart 11 that the students are more polarized in answering the question regarding the presence of the elements of multicultural education in curricula than in their answers to other questions. This can be explained by their vested interest in education and the shaping of the curriculum. Hence students affiliated with the nationalist party do not support the inclusion of multicultural education, which is in accordance with their party line: $75.68 \%$ think that there should not be elements of multicultural education while $24.32 \%$ think that there should be. There is a sharp divergence between them and students affiliated with the democratic group, of whom $68.64 \%$ support the inclusion of multicultural elements and $31.36 \%$ do not. Socialists and undecided students do not differ greatly from the democrats. $54.79 \%$ of the undecided and $62.5 \%$ from the socialist block think there should be multicultural elements and $45.21 \%$ and $37.5 \%$ respectively think there should not. Here the difference between the students from the nationalist block and those from other parties is most pronounced, the difference between nationalists and democrats being 44.32\%, nationalists and undecided $30.47 \%$ and nationalists and socialists $38.18 \%$. By comparison, the difference between socialists and undecided is $7.71 \%$, democrats and undecided $13.85 \%$ and democrats and socialists $6.14 \%$. This pattern of dissimilarity and division along party lines points to the fact that in Serbia in the past decade, the democratic and socialist blocks have begun to share the same body of voters, which has resulted in their having overlapping political ideologies and practices. In the previous two mandates the democratic and socialist block formed the majority in the parliament and the government. 


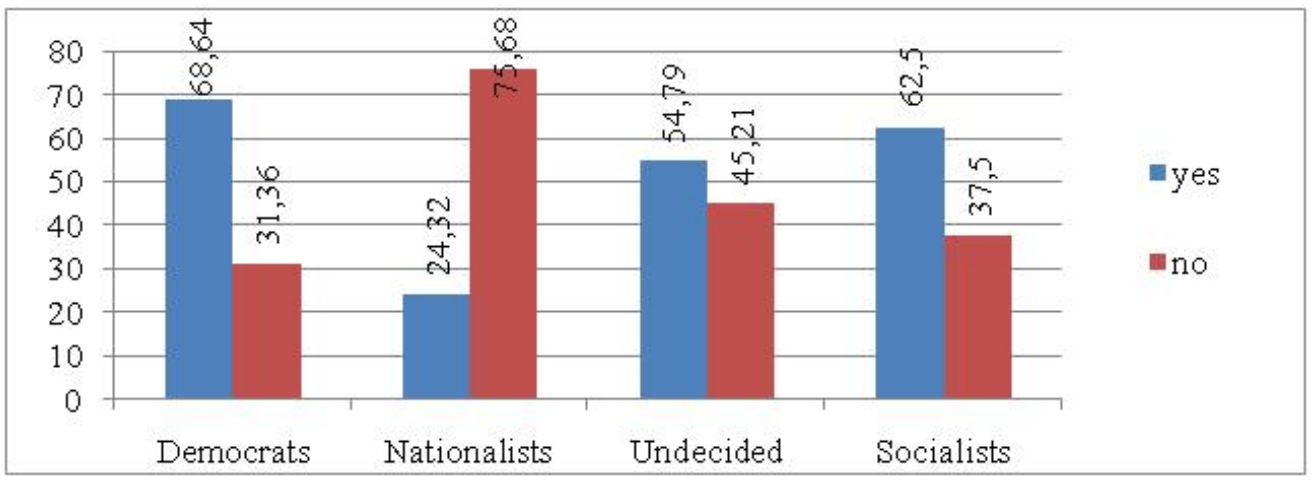

Chart 11

There is less opposition between men and women in each party group which can be attributed to party ideology (Chart 12). There is an $11.77 \%$ difference between male and female democrats, which can be explained by this party group's greater flexibility, one of $6.67 \%$ between socialist men and women, and one of $8.48 \%$ between undecided male and female students. The difference of only $1.47 \%$ between male and female nationalists reflects rigidity in this party block and greater allegiance to the party. Interestingly, again the greatest disparity can be found among women. While $74.42 \%$ of female democrats support the inclusion of multicultural elements, $76.47 \%$ of female nationalists do not, the difference being $50.89 \%$. Here the difference between men is also more pronounced than was the case with previous questions (the disparity ranges from $38 \%$ between nationalists and democrats to $25 \%$ between nationalists and undecided). Male democrats and male nationalists differ by $37.65 \%$ in their answers. The divergence between female nationalists and 
socialists is $43.14 \%$ while for their male counterparts it is $35 \%$. The difference between female nationalists and undecided female students is exactly the same, $35 \%$, and for male students from the same groups it is $25 \%$. In comparison with this, the differences between women and men from the democratic and socialist block and those who are undecided are not as substantial. Democratic and undecided women differ by $15.94 \%$ and their male counterparts by $12.65 \%$. Democratic and socialist women differ by $7.75 \%$ and men by $2.65 \%$.

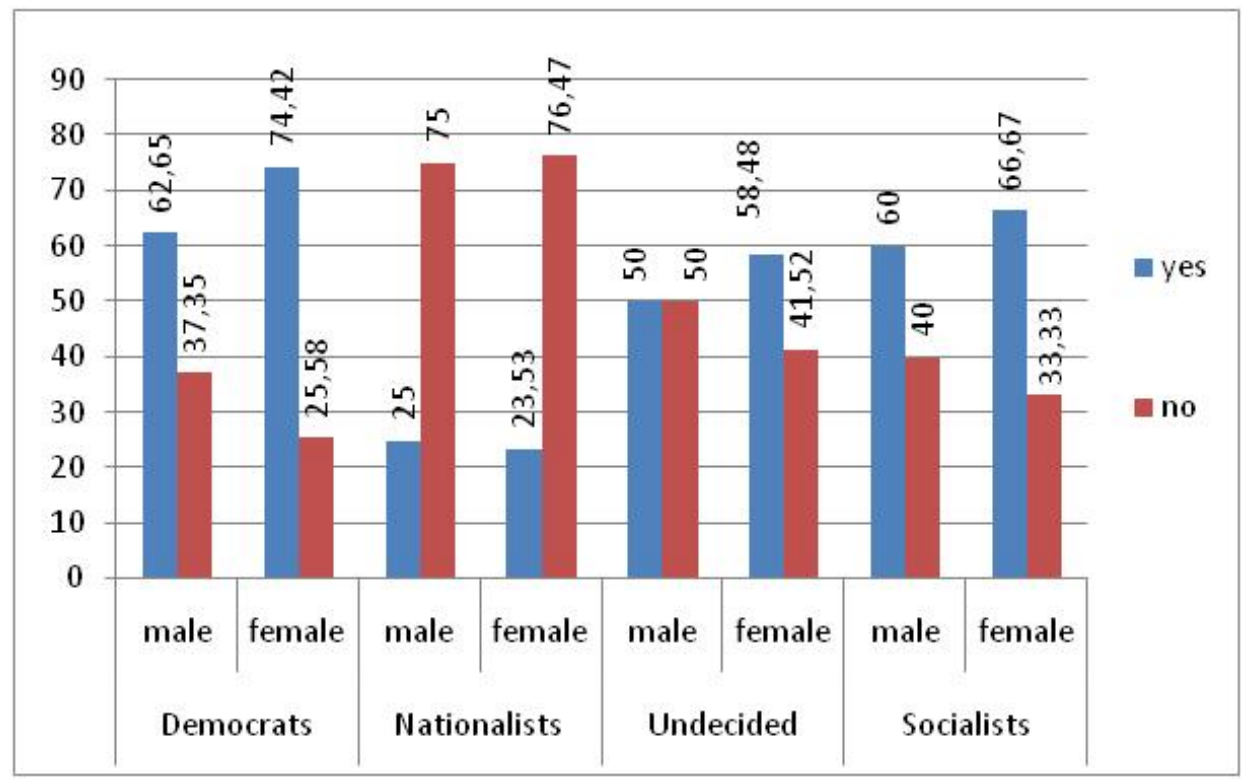

Chart 12

At the same time, the differences between women and men from the democratic and socialist block and those who are undecided are not so prominent $(12 \%)$. Male democrats and male nationalists differ by $37.65 \%$ in their answers. The divergence between female nationalists and socialists is $43.14 \%$ and for their male counterparts it is $35 \%$. The difference between 
female nationalists and undecided female students is $34.95 \%$ and for male students from the same groups it is $25 \%$. By contrast, once more it is women and men from the democratic and socialist blocks and those who are undecided who do not differ substantially. Democratic and undecided women differ by $15.94 \%$ and their male counterparts by $12.65 \%$. Democratic and socialist women differ by $7.75 \%$ and men by $2.65 \%$. Thus, we see that women affiliated with the nationalist party are again more decisive in their negative attitudes toward multicultural education, but this time they are closely followed by their male counterparts. Unlike them, the students from other party groups and those who are undecided have realized the need for multicultural education and would like to see it included in their courses. This reflects their support for equality and for the rights of ethnic minorities.

\subsection{Influence of Multicultural Education on Ethnic Tolerance}

Women tend to place a higher value on the influence of multicultural education (Chart 13). $86.57 \%$ of women think that they have become more tolerant thanks to multicultural education in comparison to $76.4 \%$ of men, while $23.6 \%$ of men think that multicultural education did not have any effect on their degree of tolerance in comparison to $13.43 \%$ of women. The difference between the genders is $10.17 \%$. Similarly, Cockrell et al. found that after attending a course on multicultural education, only women changed their position in the direction of a more positive perception of multicultural education while men retained their former belief in monocultural education (Cockrell et al., 1999:386). 


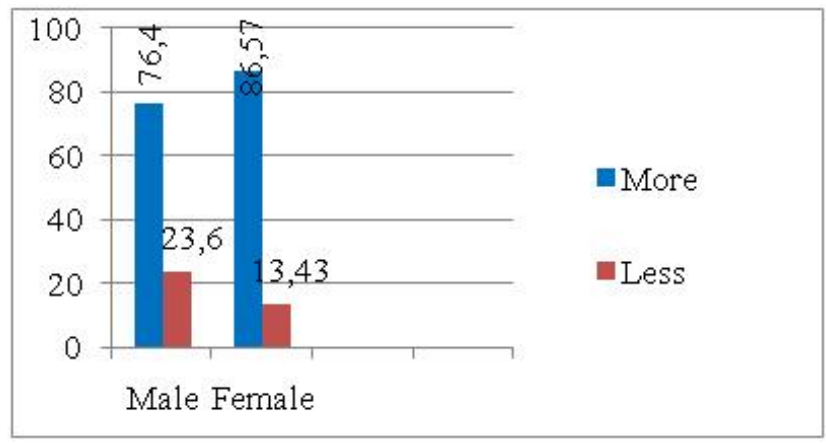

Chart 13

Analysis of the results in relation to party affiliation confirms our previous findings (Chart 14). There is a major difference of $29.3 \%$ between nationalists and democrats, with the democrats favouring the influence of multicultural education and nationalists perceiving it negatively. Democrats, socialists and the undecided form a united block in their positive opinion about multicultural education and their divergence from the nationalist position, with differences between them not exceeding $7 \%$.

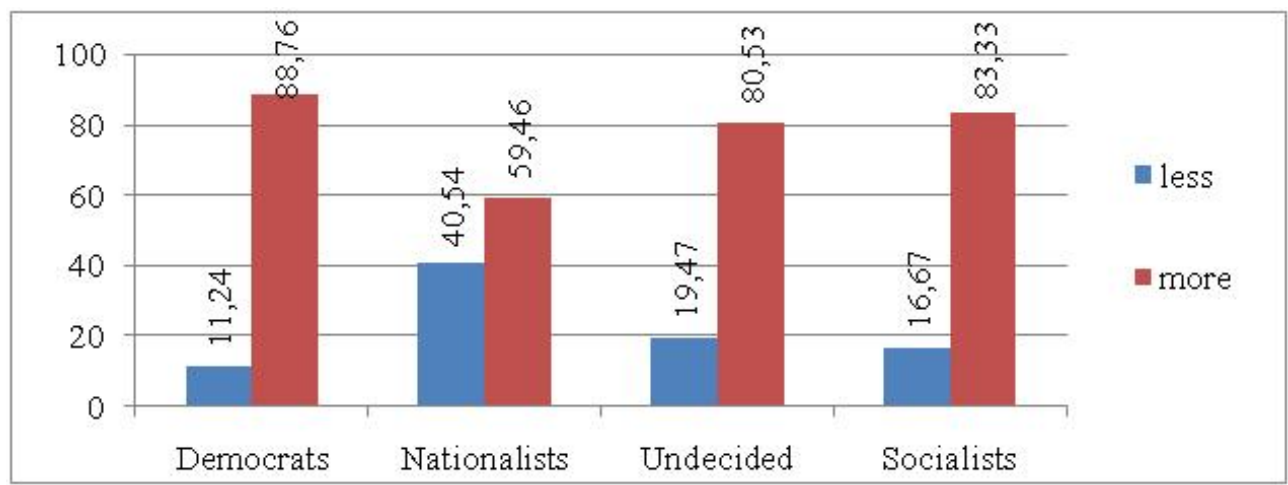

Chart 14 
The differences between men and women who belong to the same party group are not very pronounced (Chart 15). Among democrats the difference is $6.32 \%$, among the undecided $12.48 \%$, among socialists $8.89 \%$ and interestingly the greatest difference is that among nationalists: $20.59 \%$. Here we have much more significant differences between men from different party blocks. Thus the difference between male democrats and nationalists is $35.54 \%$, nationalists and undecided men $23,48 \%$ and nationalists and socialists $36.67 \%$. The disparity between male students from the democratic and the socialist group is negligible.

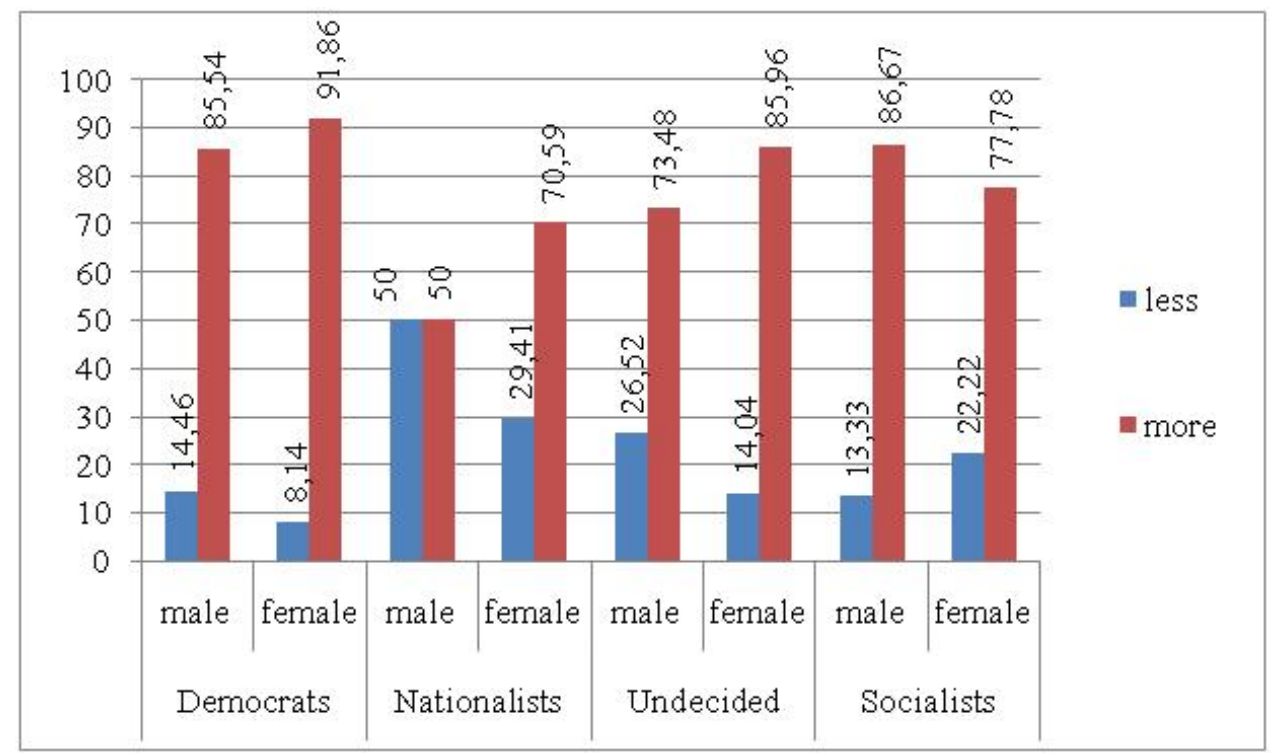

Chart 15

Another novelty here is the less noticeable difference among women. Female democrats differ from female nationalists by $21.27 \%$, female 
nationalists and undecided female students by $15.37 \%$. We can see a slightly higher divergence between female students affiliated with the democratic and socialist blocks, $14.08 \%$, while there is less difference between female democrats and undecided women, 5.9\%, and socialists and undecided women, $8.18 \%$. Interestingly there is also a much smaller difference between female nationalists and socialists than is usually the case: $7.19 \%$.

More marked differences between men and women from the same party (particularly nationalists) and smaller differences between women from different party blocks can be explained by the general tendency of women to be more tolerant and supportive of ethnic minorities. This is usually ascribed to the marginalized position both women and ethnic minorities share in patriarchal societies. This also explains the greater disparity among men from different parties. We can also assume that men are less tolerant of ethnic minorities since in the Balkans men are perceived as warriors and in Serbia it is particularly among men that the memories of recent civil war and ethnic conflicts are unfortunately still fresh. In comparison, more women in Serbia from all walks of life were actively involved in peace movements (Blagojević 1997:23).

\subsection{The Students' Perception of Serbia}

Obviously, the leading party/coalition has a decisive role in the creation of educational policy. Therefore, it matters a great deal how the generations of students who are presently at university perceive their political affiliation, because they, by their votes, will determine the future course not only of political parties but of the whole of society. The regrouping of parties on the Serbian political scene, which is reflected in the students' answers regarding 
their perception of Serbia, points to the fact that this alignment will most probably have an impact on educational policy, including on the inclusion or non-inclusion of multicultural education. This is why we considered it relevant to examine the students' perception of their country. Party affiliation was a stronger predictor here than the gender aspect. There is very little difference between male and female students in their perception of Serbia (Chart 16). 3\% more female students have a positive view while $3 \%$ more male students have a negative view.

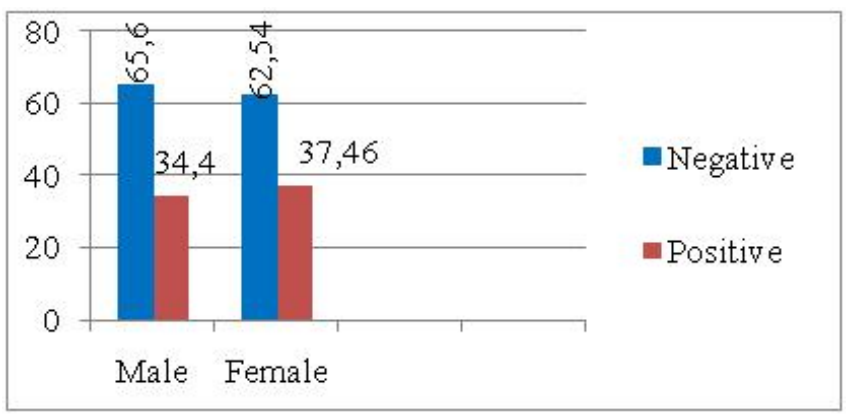

Chart 16

Polarization in relation to the students' perception of Serbia is evident not so much in terms of democrats, socialists and undecided versus nationalists as in the comparison between democrats and undecided on the one hand and socialists on the other (Chart 17). This rift in this otherwise quite uniform block can be attributed to the history of socialist and nationalist groups in Serbia and more importantly to their slow but sure progress, reflected in their larger share of voting support. The rise of both parties is remarkable given their problematic past and their participation in the civil war and in Milosevic's 
regime. The socialists in particular, who struggled under the heavy burden of responsibility for the downfall of the Milosevic dictatorship, severe economic crises, the loss of Kosovo and defeat at the polls, have managed to completely reverse their ideology and party image. They have presented themselves as the moderate party of the centre, entered coalitions with the democratic groups and gained popularity. Similarly, the nationalist group has reversed its image as the party responsible for ethnic intolerance and ethnic cleansing during the civil war and presented itself as a group supporting both Serbian national interests and entrance into the EU. These stances obviously worked, since after the last elections the socialists and nationalists formed the government. Unlike them, the democrats did not fulfil the expectations of their electorate since they did not alleviate the effects of the economic crises, did not solve the problem of Kosovo's secession and did not achieve entrance into the EU. These political differences are clearly reflected in the answers given by the students.

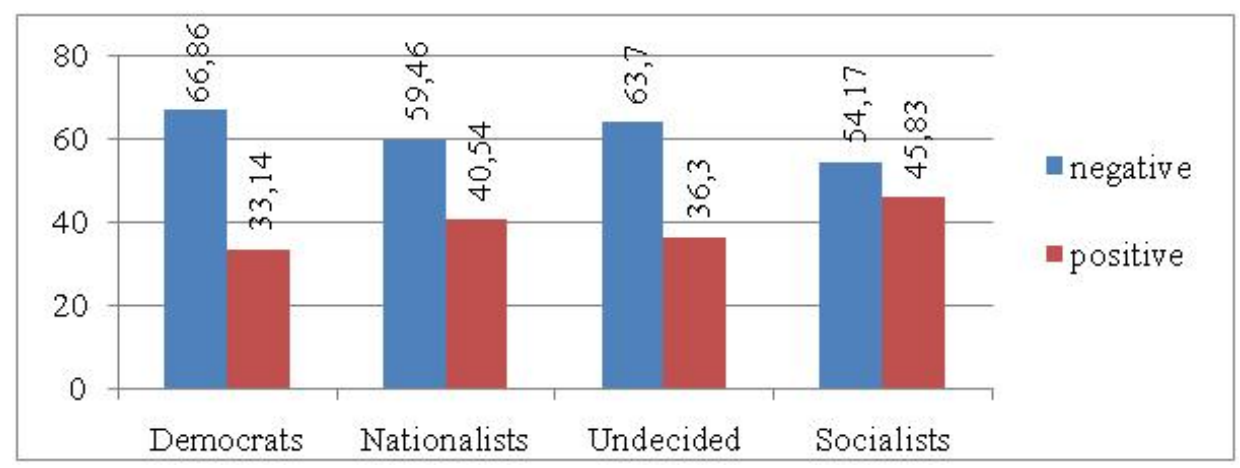

Chart 17.

Thus $45.83 \%$ of students affiliated with the socialists and $40.54 \%$ of nationalists have positive views of Serbia and the difference between them is 
only $5.29 \%$. By contrast, only $33.14 \%$ of those affiliated with the democratic block and $36.3 \%$ of the undecided are positive. The difference between democrats and socialists is $12.69 \%$ and that between the undecided and socialists $9.53 \%$. Smaller differences between nationalists and democrats (7.4\%) and nationalists and the undecided (4.2\%) can be explained by the gradual shift of the democratic party towards the centre following the example of the nationalist and socialist blocks.

The intersection of gender and political affiliation in this case reflects the above-mentioned differences between the political groups (Chart 18). Consequently, the greatest difference is between male democrats and socialists $(14.14 \%))$ and female democrats and socialists $(10.72 \%)$. We do however see more of a difference between male socialists and undecided male students $(14.95 \%)$ than between their female counterparts (5.26\%). Likewise, there is less difference between female nationalists and undecided (9.15\%) and their male counterparts $(12.42 \%)$. The same goes for male nationalists and male democrats (12.47\%) and female ones respectively (1.57\%). 


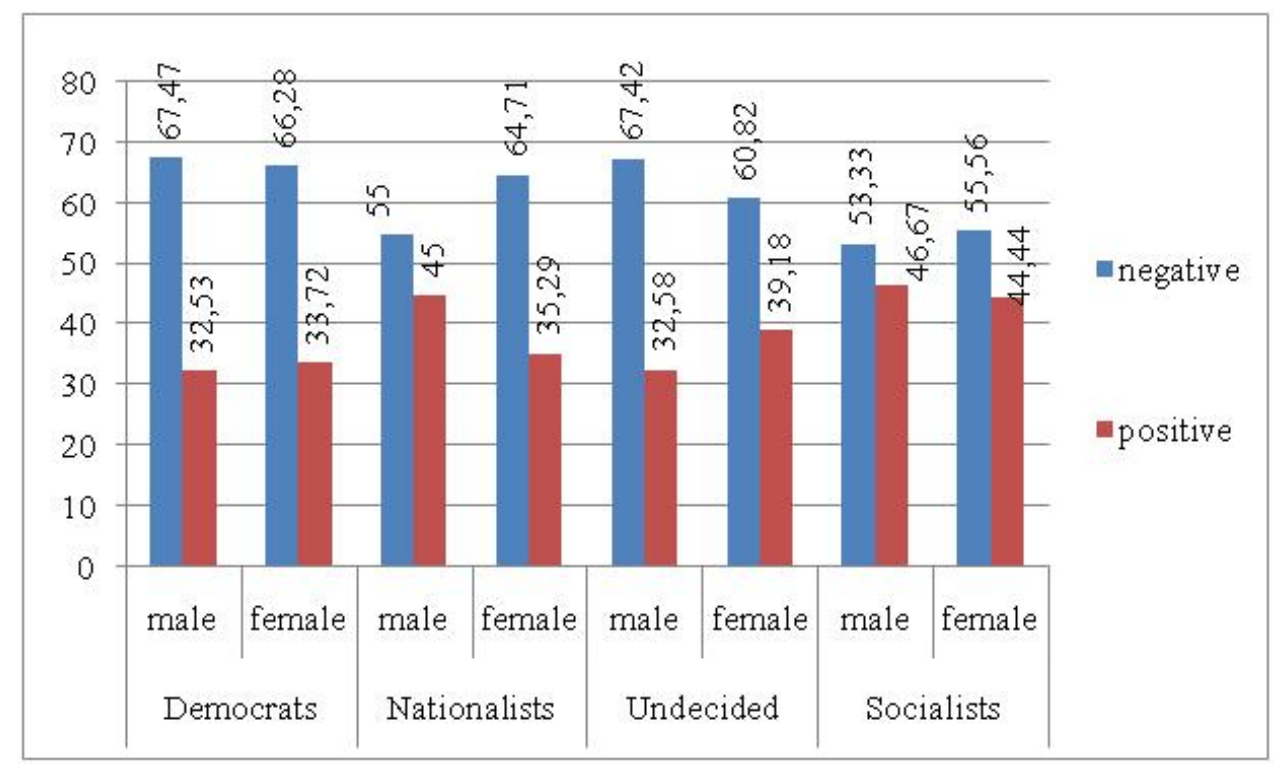

Chart 18

\section{Conclusions}

The results of our research confirm our hypothesis that gender and political affiliation have an influence on shaping the attitudes of students at the University of Novi Sad towards ethnic minorities in Serbia and the importance of multicultural education. Students at the University of Novi Sad, especially women, students who affiliate themselves with the democratic and socialist parties and unaffiliated students, have a positive opinion of multicultural education, which is an important factor in the diverse cultural context of Vojvodina. By contrast, students affiliated with the nationalist group have a negative attitude to this kind of education. Thus it can be said that democrats, socialists and the politically unaffiliated form a united block in their positive opinion about multicultural education while the nationalist group with its 
negative attitude to this kind of education forms the opposing block. There are greater differences in attitude among women who belong to different political groups than among men, particularly between female democrats and female nationalists. The reason for this, the greatest difference seen among women in our sample, can be traced back to the history of the political groups with which they affiliate themselves. Nationalist parties have only recently started to give women leading positions within the party and government. Party discipline and loyalty thus became for women a prerequisite for advancing through the ranks and this adherence to party ideology can clearly be seen in their answers. On the other hand, women who belong to the democratic block have a long history of ideological diversity within their party and are accordingly less uniform in their opinions. More importantly, women had leading roles in the democratic block in Serbia from the beginning and occupied prominent positions in the government because of their struggle for women's rights. It is no wonder, then, that the opinions of women from these two blocks are so diametrically opposite, and this is also evident in their attitudes toward multicultural education. These differences are also more noticeable than differences among men and women who belong to the same party. The greater disparity seen between men and women who belong to the democratic block in comparison with those who align themselves with nationalist ideology can be explained by flexibility and rigidity within the two parties respectively. We can therefore say that one of the more characteristic and noteworthy findings of our research was the conclusion that the gender aspect is more apparent in the differences between women than between either different men or men and women. The differences between men from different party blocks were statistically less significant, which can be 
explained by their safer positions within the party hierarchy and the absence of a need to prove their loyalty to party ideology. In the students' perception of Serbia we can also see an intersection of gender and political affiliation which reflects the differences among political groups. This confirms the relevance of the intersection of gender and political affiliation (which was one of the goals of our research). We believe that this research is relevant for creators of educational programs and policies in Serbia. It also points the way for future research, since this was the first piece of research carried out in Serbia to examine the attitudes of students towards multicultural education and ethnic minorities. Similar research needs to be carried out at different levels of the education system in Serbia (primary and high schools) among both students and educators. Moreover, our results, which confirm our hypothesis that both gender and the political affiliation of the students shape their attitudes, have led us to conclude firstly that we need to analyze the influence of the same factors on the opinions of educators and secondly that we should investigate how other variables such as ethnicity, class and religion (to name just a few of the most significant ones) affect their perception of multicultural education. Given that Serbia has before it a serious task of revising its educational system to make it more inclusive and accessible to students with special needs, such studies are indispensable in order to make us more aware of the views of those who are responsible for putting these educational programs into practice. Abundant research shows that if educators, particularly pre-service teachers, are not acquainted with the benefits of inclusive and multicultural education, they become the most serious impediment to its successful implementation (Izgarjan and Prodanović-Stankić 2012:165; Cockrell 1999:352; Abrams and Gibson 
2007:150). We hope that this study will prove one of the steps towards that goal.

\section{References:}

Abrams S., Laura and Gibson, Priscilla. 2007. "Reframing Multicultural Education: Teaching White Privilege in the Social Work Curriculum”, Journal of Social Work Education 43 (1): $147-160$.

Blagojević Marina. 1997. "Jaja i zviždaljke.” Feminističke sveske 7-8: 20-35.

Cockrell Karen et al. 1999. “Coming to Terms with 'Diversity' and 'Multiculturalism' in Teacher Education: Learning about our Students, Changing our Practice." Teaching and Teacher Education 15: 351-366.

Hidalgo, Francisco. "Multicultural Education Landscape for Reform in the Twenty-first Century" http://education.nmsu.edu/faculty/ci/ruchavez/ publications/8-MULTICULTURAL\%20EDUCATION.htm. [Accessed 2013 June 10]

Izgarjan, Aleksandra, Markov, Slobodanka and Prodanović-Stankić, Diana. 2012. "Gender Aspects in the Attitudes of the Students of the University of Novi Sad towards Multiculturalism." Gender Studies 11: 251-265.

Izgarjan, Aleksandra and Prodanović-Stankić, Diana. 2012. "Importance of Multicultural Education and Possible Implications in Serbia.” Nastava i vaspitanje: časopis za pedagošku teoriju i praksu LXI (1):156-169.

Mlađenović, Lepa. 2002. 'Nasilje nad ženama je pojačano', Karavan, Žene Balkana: regionalna perspektiva, 7 (2002), 20.

Kehrberg, ReNae S . 1990. “An Assessment of Nonsexist Multicultural Education” (January 1, 1990). ETD collection for University of Nebraska - Lincoln.

PaperAI9030128.http://digitalcommons.unl.edu/dissertations/AAI9030128. [Accessed 2013 May 23]

Seltzer, Richard et al. 1995. "Multiculturalism, Race, and Education." The Journal of Negro Education 64 (2): 124-140. 